\title{
Dynamics of autotrophic picoplankton communities in the epilimnion of a eutrophic lake (Strzeszyńskie Lake, Poland)
}

\author{
E. Szelag-Wasielewska
}

Department of Water Protection, Adam Mickiewicz University, Drzymaty 24, 60-613 Poznań, Poland. E-mail: rgold@amu.edu.pl

\begin{abstract}
The results of 32 seasonal sampling sessions in 2000 were used to assess the dynamics of autotrophic picoplankton (APP), with special reference to the cyanobacterial component in Strzeszyńskie Lake, a eutrophic lake in mid-western Poland. The abundance of picocyanobacteria (Pcy) fluctuated from $1.2 \times 10^{4}$ to $8.1 \times 10^{5}$ cells $\mathrm{mL}^{-1}$ and the average abundance and biomass were $2.0 \times 10^{5}$ cells $\mathrm{mL}^{-1}$ and $0.094 \mathrm{mg} \mathrm{L}^{-1}$, respectively. Pcy development was characterised by maxima in spring and summer. The summer maximum was twice the spring Pcy numbers. Eukaryotic APP (E-APP) were also present but in low numbers and their annual average contribution to the total APP community was only about $0.3 \%$ in abundance and about $3 \%$ in biomass. The spring Pcy community was dominated by single-celled cyanobacteria (S-Pcy) and in summer by colonial forms (C-Pcy). Throughout the sampling period, C-Pcy constituted on average 55\% of the total Pcy and up to $90 \%$ in summer. C-Pcy abundance was significantly and positively correlated with water temperature $(r=0.40, p=0.023, n=32)$. S-Pcy exhibited a distinct seasonal variation in FDC, ranging from $10 \%$ to $35 \%$. Most FDC values above $30 \%$ were recorded from late May to mid July.
\end{abstract}

Keywords : picocyanobacteria, seasonal fluctuations, single cells, colonial forms, frequency of dividing cells, eutrophic lake.

\section{Introduction}

In freshwater ecosystems, autotrophic picoplankton (APP) was observed for the first time and later studied more intensively in oligotrophic and mesotrophic lakes, so the majority of APP studies concern these habitats (Stockner 1988, 1991, Weisse 1993, Stockner et al. 2000). Seasonal variations in APP abundance, and issues associated with APP production and importance in pelagic communities are also better known in oligotrophic and mesotrophic rather than in eutrophic and hypertrophic water bodies, so that the general situation of the picoplankton communities is often ambiguous in the two latter habitats (Sime-Ngando 1995, Sommaruga \& Robarts 1997). Great seasonal variation in APP abundance and biomass has been reported, with highest values mostly recorded in late summer. In this season picocyanobacteria population tend to be predominant in lakes with neutral to alkaline water but among them we still need more research concerning seasonal patters of the colonial forms and their proportion in the seasonal succession of the APP community (Stockner et al. 2000). The contribution of APP to total pelagic production also varies considerably, although mean values are usually high, at least in some seasons (Weisse 1993, Stockner et al. 2000). However, recent results suggest that those values might have been overestimated (Happey-Wood 1994, Fahnenstiel et al. 1994). Because of this, the frequency of dividing cells (FDC) has been recommended to estimate productivity directly and carbon dynamics of the picocyanobacterial size fraction (Affronti \& Marshal 1994, Callieri et al. 1996). Therefore, it is also necessary to determine the range of seasonal variation of FDC in eutrophic lakes.

In this study, seasonal fluctuations in some population parameters of cyanobacteria and eukaryotic cells of picoplanktonic size were investigated by epifluorescence microscopy. The main objective was to determine seasonal changes in: (1) abundance and biomass of those two groups of picoplanktonic phototrophs; (2) contributions of single-celled and colonial forms within picocyanobacteria; and (3) FDC for picocyanobacteria in the eutrophic Strzeszyńskie Lake. Following preliminary investigations in 1993 and 1996, more intensive research was carried out in 2000, when the lake epilimnion was sampled 32 times. Such a sampling frequency made it possible to assess the seasonal dynamics of the APP community.

Article available at http://www.limnology-journal.org or http://dx.doi.org/10.1051/limn/2004009 


\section{Materials and methods}

\section{Study site}

The Strzeszyńskie Lake is situated in mid-western Poland $\left(52^{\circ} 28^{\prime} \mathrm{N}, 16^{\circ} 49^{\prime} \mathrm{E}\right)$ within the city of Poznan. The lake is of glacial origin, located $76.8 \mathrm{~m}$ above sea level at the head of the Bogdanka River. Strzeszyńskie Lake has an area of 34.9 ha, a volume of $2.8 \times 10^{6} \mathrm{~m}^{3}$, a maximum depth of $17.8 \mathrm{~m}$ and a mean depth of $8.2 \mathrm{~m}$. Earlier investigations indicated that Strzeszyńskie Lake is dimictic and eutrophic (Szelag-Wasielewska 1999a). Thermal stratification develops between May and October. In summer an oxygen deficit develops below $8 \mathrm{~m}$ and usually anaerobic conditions are observed below $10 \mathrm{~m}$, while surface waters are often supersaturated with oxygen. The total phosphorus concentration in surface waters varies from 16 to $132 \mu \mathrm{g} \mathrm{P} \mathrm{L}$ ${ }^{1}$, dissolved oxygen from 7.4 to $15.8 \mathrm{mg} \mathrm{O}_{2} \mathrm{~L}^{-1}$, chlorophyll $a$ concentration from 0.1 to $12.4 \mu \mathrm{g} \mathrm{L}^{-1}$, and dry mass of seston from 0.2 to $5.9 \mathrm{mg} \mathrm{L}^{-1}$.

During this investigated period, water temperatures were measured each time. They ranged from 6.6 to $25.8^{\circ} \mathrm{C}$ and two peaks were observed in late July $\left(25.8^{\circ} \mathrm{C}\right)$ and August $\left(23.4^{\circ} \mathrm{C}\right)$. Secchi depth was measured from July onwards and varied between 1.2 in August and $5.9 \mathrm{~m}$ in October. The phytoplankton community showed substantial seasonal fluctuations: the maximum biomass was recorded in mid-summer, and the dominant groups were successively: diatoms, chrysophytes, chlorophytes, and cyanobacteria. 144 taxa were found between May and November (12 sampling sessions). The most numerous among diatoms were: Cyclotella spp. and Asterionella formosa; among chlorophytes: Chlorella, Eutetramorus, Scenedesmus and Oocystis spp.; among chrysophytes: Dinobryon divergens, and Ochromonas spp.; among cyanobacteria: Aphanocapsa, Aphanothece and Microcystis spp.; among cryptomonads: Rhodomonas lacustris and Cryptomonas spp. In the zooplankton, rotifers were more abundant than crustaceans. Between May and August, when they were monitored, the average density of rotifers was 523 ind. $\mathrm{L}^{-1}$ (10 sampling sessions) with a maximum in late July $\left(1 \times 10^{3}\right.$ ind. $\left.\mathrm{L}^{-1}\right)$. Three taxa of rotifers dominated: Keratella cochlearis, Pompholyx sulcata, and Polyarthra spp. Daphnia cucullata and Bosmina coregoni were the most common cladocerans, with a maximum in May, when the clear-water phase occurred. Among copepods, mainly juvenile stages of Eudiaptomus and Mesocyclops occurred.

\section{Sampling and analytical methods}

The sampling station was situated in the pelagic zone of the lake, $0.5 \mathrm{~m}$ below the water surface. Samples for APP analysis were taken 32 times, from late April to mid-December of 2000, at intervals of 1-3 days or 13 weeks and always in the afternoon or early evening. The samples were preserved immediately in $100-\mathrm{mL}$ sterile bottles with buffered glutaraldehyde to a final concentration of $1 \%$.

The samples for APP counts were stored in darkness at $4{ }^{\circ} \mathrm{C}$ and processed within one week after sampling. Subsamples of 1-3 mL volume were collected by filtration on black Nuclepore filters of $0.2-\mu \mathrm{m}$ pore size at a low vacuum pressure, and then stained with the fluorochrome DAPI (Porter \& Feig 1980). DAPI staining was used, because changes in excitation light from green through blue and violet-blue to ultraviolet helped to identify the stage of cell division and to localize some cell components. Twenty to sixty fields (in two or three replicates) were examined, or at least 200 cells were counted at a magnification of $1500 x$ under an Olympus BX-60 microscope equipped with an HBO 100W lamp and filter set for green (G: BP 510550, DM 570, BA 590), blue (B: BP 450-480, DM 500, BA 515), blue-violet (BV: BP 400-420, DM 455, BA 475), and ultra-violet (UV: BP 330-385, DM 400, BA 420) light excitation. When colonial picocyanobacteria were present, lower magnifications were also used $(300 \mathrm{x}$ or $600 \mathrm{x})$ and a larger proportion of the filter area was investigated (several transects or the whole filter).

APP was classified as prokaryotic or eukaryotic on the basis of autofluorescence colour, shape and size of cells (MacIsaac \& Stockner 1993). Two morphogroups of picocyanobacteria according to Stockner et al. (2000) were distinguished, single cells and colonies with diverse colonial morphology. The identification of picoeukaryotes was based on the shape and location of chloroplast, presence or absence of pyrenoids, location of the nucleus, and mode of reproduction. The FDC for single celled picocyanobacteria of $0.2-2.0 \mu \mathrm{m}$ in size and two to four-celled aggregates was also estimated under the epifluorescence microscope. The FDC was not assessed for colonial picocyanobacteria, because in dense colonies some cells could not be seen. The size dimensions of cells were measured using an image-analysis system (analySIS). The biomass of each taxa was estimated from average cell volume and abundance, and was expressed as wet weight, assuming that the volume of $10^{6} \mu \mathrm{m}^{3}$ is equivalent to $1 \mu \mathrm{g}$. 
The statistical analysis of the results included the calculation of linear correlation coefficients. STATISTICA 5.5 software was used for the analysis.

\section{Results}

The APP communities development in Strzeszyńskie Lake was characterized by maxima in spring and summer. A high abundance of APP was observed in late April and from mid-July to mid-September, with a peak on 24 August (Fig. 1). Pcy abundance, the main APP component, fluctuated from $1.2 \times 10^{4}$ to $8.1 \times 10^{5}$ cells $\mathrm{mL}^{-1}$ (mean $2.0 \times 10^{5}$ cells $\mathrm{mL}^{-1}$ ). The spring Pcy community was dominated by single-celled picocyanobacteria (S-Pcy, likely Synechococcus, Synechocystis) and in summer by colonial forms (C-Pcy). Most of the latter, based on morphological characteristics (Komárek \& Anagnostidis 1999), were identified as species from the genera Aphanocapsa and Aphanothece. Among them Aphanocapsa holsatica (Lemm.) Cronberg et Komárek, A. delicatissima W. et G.S. West, $A$. incerta (Lemm.) Cronberg et Komárek and Aphanothece bachmanii Komárková-Legnerová et Cronberg were the most common. S-Pcy were most abundant in late April $\left(3.8 \times 10^{5}\right.$ cells $\left.\mathrm{mL}^{-1}\right)$, but decreased rapidly and remained at low densities throughout the rest of the year. C-Pcy were first recorded in June. Initially their numbers were very low, but in July they increased rapidly (Fig. 2). Their contribution to total

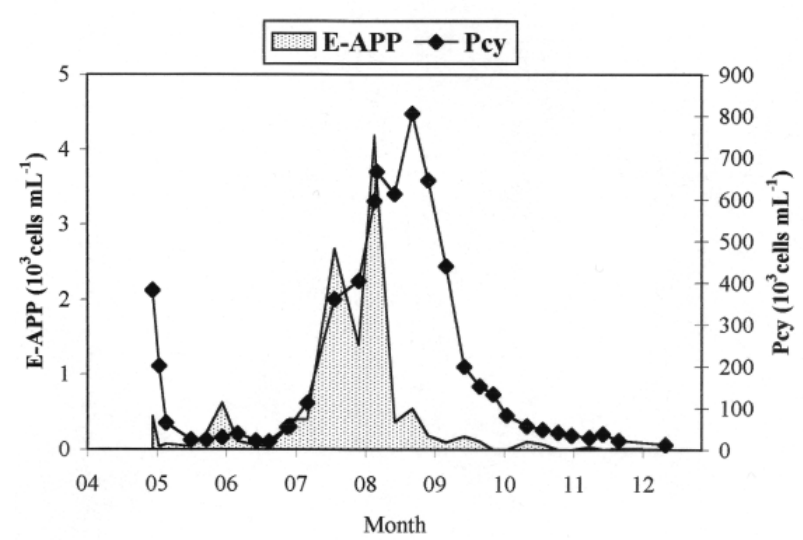

Fig. 1. Picocyanobacteria (Pcy) and eukaryotic APP (E-APP) abundance in Strzeszyńskie Lake from April to December 2000.
Pcy abundance for 4 months (July-October) was over $60 \%$, and was over $90 \%$ between late July and September. In early November their contribution decreased to about $50 \%$, and in the last month of the study period to $10 \%$. On average, from April to December, the contribution of cells forming colonies was 55\% (range 0-97\%). The second component of APP, the eukaryotic APP (E-APP), reached its highest abundance from July to August with a maximum in early August $\left(4.2 \times 10^{3}\right.$ cells $\left.\mathrm{mL}^{-1}\right)$ (Fig. 1). The main representatives of E-APP were chlorophytes of the genera Chlorella and Choricystis minor (Skuja) Fott. The annual mean abundance of E-APP was $0.51 \times 10^{3}$ cells $\mathrm{mL}^{-1}$ and the annual contribution to total APP varied between 0 and only $2.1 \%$ (mean value $0.28 \%$ ).

The volume of Pcy spherical cells varied from 0.38 to $0.91 \mu \mathrm{m}^{3}$ and rod cells from 0.64 to $0.95 \mu \mathrm{m}^{3}$, while E-APP cell volume was usually higher: mean spherical cells $-4.19 \mu \mathrm{m}^{3}$ and ellipsoidal or slightly kidney shaped $-1.85 \mu \mathrm{m}^{3}$. The seasonal variations in APP community biomass are presented in figure 3 . Total biomass ranged from $0.005 \mathrm{mg} \mathrm{L}^{-1}$ in December to 0.380 $\mathrm{mg} \mathrm{L}^{-1}$ in August, whereas that of Pcy ranged from 0.005 to $0.378 \mathrm{mg} \mathrm{L}^{-1}$ (mean $0.097 \mathrm{mg} \mathrm{L}^{-1}$ ) and that of E-APP from 0 to $0.018 \mathrm{mg} \mathrm{L}^{-1}$ (mean $0.002 \mathrm{mg} \mathrm{L}^{-1}$ ). The pattern of changes in biomass during the study period was similar to the observed changes in abundance. It is noteworthy that APP biomass markedly decreased during the clear-water phase, i.e. in late May and in June and the biomass of Pcy was always higher (usually over 10 times higher) than that of E-APP biomass. Pcy accounted for $77-100 \%$ of total APP bio-

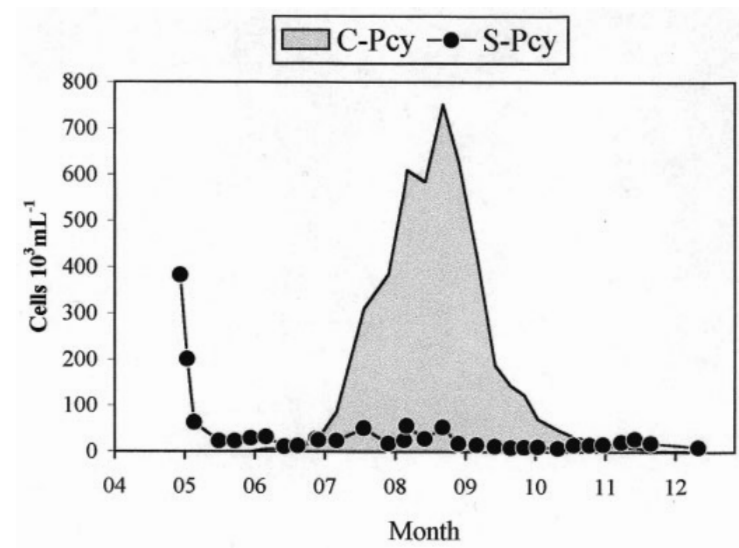

Fig. 2. Colonial (C-Pcy) and single-celled picocyanobacteria (SPcy) abundance in Strzeszyńskie Lake from April to December 2000. 


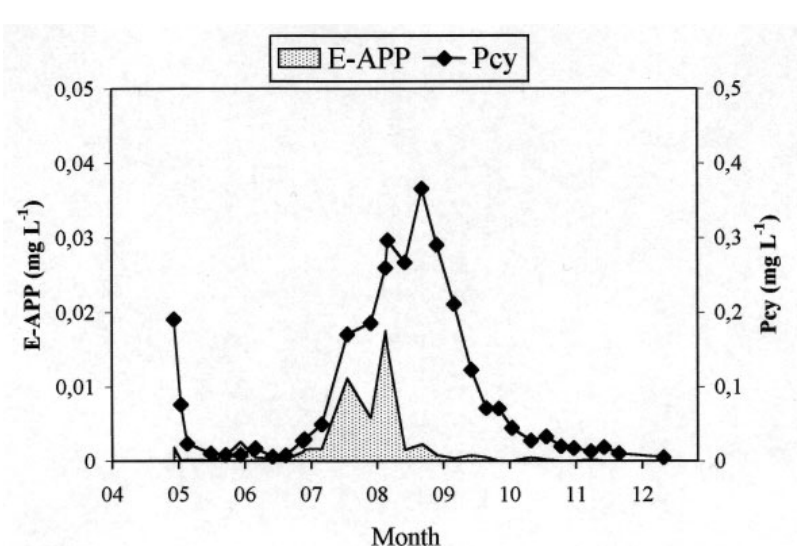

Fig. 3. Picocyanobacteria (Pcy) and eukaryotic APP (E-APP) biomass in Strzeszyńskie Lake from April to December 2000.

mass (mean $97.5 \%$ ), while E-APP for $0-23 \%$ (mean $2.5 \%$ ). The highest contribution of E-APP to total APP biomass was recorded in late May, when Pcy was less abundant than in other periods. Both Pcy and E-APP reached maximum values in summer, although their abundance and biomass were very different and peaks did not occurr at the same time.

The water temperature and abundance of C-Pcy was significantly and positively correlated $(r=0.401$, $\mathrm{p}=0.023, \mathrm{n}=32)$ ). In contrast, the abundance of S-Pcy and E-APP was not significantly correlated with water temperature. Water transparency declined while abundance of Pcy increased. This decline of transparency

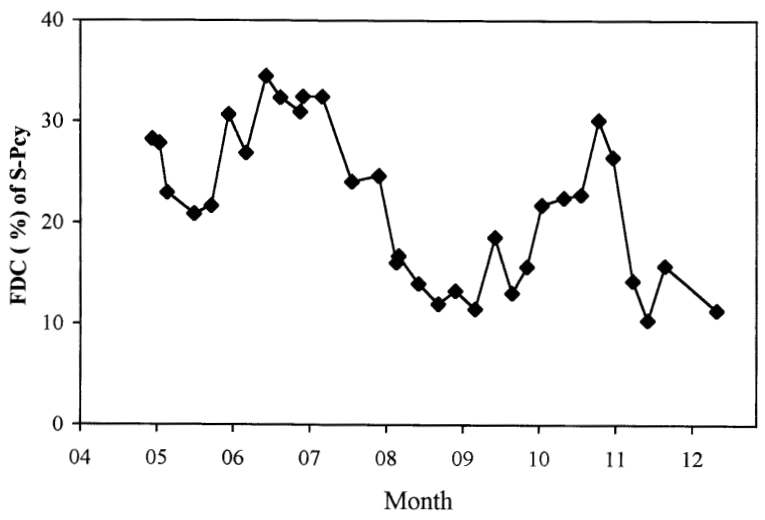

Fig. 4. Seasonal pattern of frequency of dividing cells (FDC) of single-celled picocyanobacteria (S-Pcy) in Strzeszyńskie Lake from April to December 2000.

was most strongly correlated with the abundance of CPcy (Table 1).

The S-Pcy exhibited a distinct seasonal variation in the FDC, ranging from $10.4 \%$ in mid November to $34.5 \%$ in mid-July (mean $=22 \%, \mathrm{n}=32$ ). Values above $30 \%$ were recorded from late May to mid July. Additionally, in the second half of the year, a clear but short-term increase in FDC values was observed in late October and early November (Fig. 4 ). In general, FDC were higher from April to July than from August to December, with mean values of $28.2 \%$ and $17.1 \%$, respectively.

Table 1. Correlations between the abundance of the different autotrophic picoplankton (APP) groups and some variables of Strzeszynskie Lake during 2000. $\mathrm{r}=$ correlation coefficients, $\mathrm{p}=$ levels of significance $: * \mathrm{p}<0.05 ; * * \mathrm{p}<0.01$. NS : not significant $(\mathrm{p}>0.05)$.

\begin{tabular}{|c|c|c|c|}
\hline & \multicolumn{2}{|c|}{ Picocyanobacteria (Pcy) } & \multirow{2}{*}{$\begin{array}{c}\text { Eukaryotic APP } \\
\text { (E-APP) }\end{array}$} \\
\hline & $\begin{array}{l}\text { Colonial } \\
\text { (C-Pcy) }\end{array}$ & $\begin{array}{c}\text { Single cells } \\
\text { (S-Pcy) }\end{array}$ & \\
\hline $\begin{array}{c}\text { Temperature } \\
n=32\end{array}$ & $\begin{array}{c}r=0.401 \\
* \\
p=0.023\end{array}$ & $\begin{array}{c}r=0.128 \\
N S \\
p=0.487\end{array}$ & $\begin{array}{c}r=0.252 \\
N S \\
p=0.163\end{array}$ \\
\hline $\begin{array}{c}\text { Transparency } \\
n=17\end{array}$ & $\begin{array}{c}\mathrm{r}=-0.714 \\
* * \\
\mathrm{p}=0.0013\end{array}$ & $\begin{array}{c}r=-0.451 \\
N S \\
p=0.069\end{array}$ & $\begin{array}{c}r=-0.356 \\
N S \\
p=0.160\end{array}$ \\
\hline
\end{tabular}




\section{Discussion}

The scope of research on phytoplankton of the eutrophic Strzeszyńskie Lake has been widened recently to include the smallest size fraction, i.e. the autotrophic picoplankton (APP). In the year 2000, the most frequent sampling period, APP occurred throughout the investigated period, reaching a maximum abundance in August - 8.1 $\times 10^{5}$ cells mL $\mathrm{m}^{-1}$. The maximum abundance was similar to that observed in Lake Mikolajskie (Jasser 1993) and Lake Kinneret (Malinsky-Rushansky et al. 1995), but not as high as in some other nutrient-rich water lakes, for example $2.1 \times 10^{6}$ cells $\mathrm{mL}^{-1}$ in

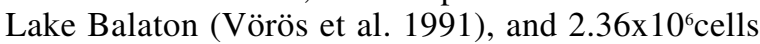
$\mathrm{mL}^{-1}$ in Lake Aydat (Sime-Ngando 1995).

The structure of the APP community of Strzeszyńskie Lake changed considerably during the investigated period. Picocyanobacteria clearly dominated, but the prevailing form changed during the year. In spring only S-Pcy were recorded, whereas C-Pcy appeared in June and later their abundance gradually increased. The Pcy community structure of Strzeszyńskie Lake was similar to that of the Slapy and Rimov reservoirs in respect of the life cycle of coccoid cyanobacteria (Komarková 2002). The situation in Lake Aydat was different, as its APP community was numerically dominated by S-Pcy. Moreover, differences concerned morphological characteristics of colonies, as in Lake Aydat aggregated picocyanobacteria consisted mainly of colonies of 4 cells each, while in Strzeszyńskie Lake colonies were often larger, composed of up to about 200 cells. Also a high concentration of picocyanobacteria and various types of cell aggregates occurred in the eutrophic water of the Central Baltic (Albertano et al. 1997).

From July till September, in Strzeszyńskie Lake, CPcy accounted for above $60 \%$ of Pcy abundance. This confirms the hypothesis formulated by Stockner et al. (2000), suggesting that colonial species find optimal conditions in warmer and more nutrient-rich lakes in summer. Nevertheless, small aggregations and large colonies of picoplanktonic cells were noted both in oligotrophic (Stockner \& Shortreed 1991, Padisák et al. 1997, Passoni \& Callieri 2000) and in mesotrophic lakes (Pick \& Agbeti 1991, Szelag-Wasielewska $1999 b)$. Even in ultra-oligotrophic lakes Pcy aggregates were observed (Stockner \& Shortreed 1994; Schallenberg \& Burns 2001). It is possible that under eutrophic conditions C-Pcy dominate in response to the pressure of consumers, while under oligotrophic conditions C-Pcy aggregate in order to reduce the in- fluence of limiting factors, for example nitrogen. Schallenberg and Burns (2001) proposed that aggregation might facilitate nitrogen fixation by non-heterocystous picocyanobacteria in the open water. It is noteworthy that during the year, trophic conditions in the epilimnion of one lake may vary greatly, so different forms of picocyanobacteria appear as a result of direct effects of nutrients and grazing pressure.

As in many other lakes, two peaks of APP abundance were observed in the study lake. The spring peak in April $\left(3.8 \times 10^{5}\right.$ cells $\left.\mathrm{mL}^{-1}\right)$ resembles the situation in the eutrophic Lake Aydat, although the maximum APP abundance in that lake was 6 times as high, reaching $2.36 \times 10^{6}$ cells $\mathrm{mL}^{-1}$ (Sime-Ngando 1995). In Lake Mikolajskie APP abundance in spring was twice as high as in Lake Strzeszyńskie, because Jasser (1993) gives the value $8 \times 10^{5}$ cells $\mathrm{mL}^{-1}$. However, it must be emphasised that when sampling in the Strzeszyńskie Lake was started in April 2000, Pcy abundance was declining rapidly and only end of the peak was recorded. The spring peak of APP abundance may prove to be frequent in nutrient-rich lakes, although its height is extremely variable. As suggested by Weisse \& Kenter (1991), Padisak \& Dokulil (1994), Sime-Ngando (1995) and Stockner et al. (2000) the peak can be easily overlooked due to insufficient sampling frequency in spring, when changes may be rapid.

The summer peak of Pcy abundance in Strzeszyńskie Lake was high and long lasting, whereas in Lake Mikolajskie picoplanktonic cell abundance was the lowest in summer (Jasser 1993). In the latter case, however, due to analytical procedure (fractionated samples) C-Pcy were not included in the data, while in Strzeszyńskie Lake C-Pcy were important components of APP in summer. In some eutrophic Danish lakes the highest APP cell densities were found in summer with minor peaks in spring (Sondergaard 1991). By contrast, in Lake Aydat (Sime-Ngando 1995) the second peak occurred during the autumn turnover.

E-APP appeared in Strzeszyńskie Lake in 2000 irregularly and only in small numbers; its mean contribution to total APP abundance was below $0.3 \%$. Also in marine environmental their abundance was often more than 10-fold lower than Pcy (Weisse 1993, Jacquet et al. 1998). Likewise, as has been noticed by some authors (Pick \& Agbeti 1991, Sondergaard 1991, Happerle and Krienitz 2001), the E-APP cells were larger than Pcy cells. However, during the study period, because of the low abundance of E-APP, their contribution to total APP biomass was also low, and their mean value increased to $2.5 \%$ in biomass only. The importance of E-APP was similar in the Slapy and Rimov re- 
servoirs (Komarkova 2002) but Sondegaard (1991) reported much higher values for the most productive Danish lakes, where eukaryotic cells dominated or were even the only components of APP. Also in Lake Balaton (Vörös et al. 1991) and Lake Aydat (Sime-Ngando 1995) E-APP were much more abundant than in Strzeszyńskie Lake, and their mean contribution to total APP abundance reached $80 \%$ and $38 \%$, respectively. However, it must be emphasized that the small number of E-APP in Strzeszyńskie Lake were often accompanied by quite numerous eukaryotic nanoplankton dominated by green algae.

The decline in abundance and biomass of both Pcy and E-APP, and their low levels for several weeks suggest that there may exist at this time a common controlling factor for these picoplankton groups, e.g. nutrients and/or grazing. It is possible that in May and June, when the clear-water phase in this lake occurred, the APP and larger phytoplankton were under strong impact of grazing. Preliminary investigations showed that metazoan zooplankton density amounted to $1.07 \mathrm{x}$ $10^{3}$ ind. $\mathrm{L}^{-1}$ in mid-May and $1.10 \times 10^{3}$ ind. $\mathrm{L}^{-1}$ in June (mostly cladocerans: Daphnia cucullata, Bosmina coregoni, rotifers: Pompholyx sulcata and species of genus Keratella). Next, in summer the density of E-APP peaked earlier than that of Pcy, but afterwards E-APP declined. This may be due to a different nutritional and growth rate of these groups (Weisse 1993).

Only two environmental factors were analysed frequently enough: water temperature and Secchi depth. Water temperature and C-Pcy abundance were positively but not strongly correlated. In six New Zealand lakes studied by Burns \& Stockner (1991), water temperature was correlated with APP abundance, which was interpreted as a result of covariance of water temperature and nutrient concentrations, light and other factors that have a stronger influence on cyanobacterial ecology. This is consistent with the conclusion drawn by Weisse (1933), suggesting that seasonal fluctuation of APP is affected less strongly by water temperature than by some other factors. However, the significant and negative association between C-Pcy abundance and Secchi depth indicates that C-Pcy communities in the study lake accounted for a significant and/or proportional part of the particles that decreased water transparency.

Although FDC for the S-Pcy population in Strzeszyńskie Lake was sometimes high the abundance of SPcy from June was relatively stable. This attests to losses as the main control of the S-Pcy density. It is possible that Pcy was then under strong impact of grazing by, for example, protozoans: some hetero- and mixotrophic flagellates, and ciliates. Those groups are considered as important consumers of picoplanktonic cells (Stockner \& Antia 1986, Stockner 1991, Fahnenstiel \& Carrick 1991, Weisse 1993, Simek et al. 1996, Amblard et al. 1998, Gaedke \& Weisse 1998, Stockner et al. 2000). The high contribution of dividing cells in the Synechococcus population may be associated with heterotrophic nanoflagellates, which select smaller, non-dividing cells. As reported by Dolan and Šimek (1999), food vacuole content was negatively related to \% of dividing Synechococcus.

In the present study all water samples from Strzeszyńskie Lake were collected in the afternoon or evening, so it can be assumed that maximal values of FDC were recorded for the population of S-Pcy because research on the diel cycle of cell division showed that FDC values were the highest in the second half of the day, most often in the afternoon or early evening (Weisse 1993, Callieri et at. 1996, Jacquet et al. 1998, Dolan \& Šimek 1999, Szelag-Wasielewska 2002). In diurnal investigation values reaching maximum were also observed in the afternoon hours (Affronti \& Marshal 1994). As stated Stockner et al. (2000) the maximum FDC of a natural population of Synechococcus is significantly correlated with the growth rate, so one measurement during the day should enable a reliable estimation of the daily production of Pcy. It should be stressed that in Strzeszyńskie Lake C-Pcy were present in the highest numbers and dominated the APP in summer-autumn and their productivity would probably exceed the values of S-Pcy.

Throughout the sampling period, except for April and early May, S-Pcy abundance was low and not highly variable, while FDC was sometimes high. This suggests that growth rates are balanced by loss rates. In such a situation the potential loss processes causing changes in Pcy numbers, e.g. grazing, including the major potential consumers of picoplankton biomass need to be investigated. Since colonial forms of Pcy dominated, first of all the role of detritivores requires further investigation because much of their biomass in the study lake perhaps enters the microbial food webs as detritus. Further investigations of the pelagial community will be needed to determine how APP, in particular Pcy as essential component of APP in this lake, is linked to other elements of the food web.

\section{Acknowledgments}

I would like to thank the following: the Dean of the Biology Faculty, A. Mickiewicz University for his financial help (Project no. PBWB-5/99), the Foundation for Polish Science, which bought a 
microscope with epifluorescence equipment (SUBIN Program), Joanna Ciachera and Jan Adam Wasielewski for support during the fieldwork, and Wanda Romanowicz for data on metazoa and two anonymous reviewers for their useful comments on the manuscript.

\section{References}

Affronti L.F. \& Marshall H.G. 1994. - Using frequency of dividing cells in estimating autotrophic picoplankton growth and productivity in the Chesapeake Bay. Hydrobiologia, 284, 193-203.

Albertano P., Di Somma D. \& Capucci E. 1997. - Cyanobacterial picoplankton from the Central Baltic Sea: cell size classification by image-analyzed fluorescence microscopy. J. Plankton Res., 19, 1405-1416.

Amblard C., Boisson J.C., Bourdier G., Fontvieille D., Gayte X. \& Sime-Ngando T. 1998. - Ecologie microbienne en milieu aquatique: des viruses aux protozoaires. Rev. Sci. Eau no spécial, 145162.

Burns C.W. \& Stockner J.G. 1991. - Picoplankton in six New Zealand lakes: abundance in relation to season and trophic state. Int. Rev. ges. Hydrobiol., 76, 523-536.

Callieri C., Bertoni R., Amicucci E., Pinolini M.L. \& Jasser I. 1996. - Growth rates of freshwater picocyanobacteria measured by FDC: problems and potentials for the estimation of picoplankton organic carbon synthesis. Arch. Hydrobiol. Spec. Issues Advanc. Limnol., 48, 93-103.

Dolan J.R. \& Simek K. 1999. - Diel periodicity in Synechococcus population and grazing by heterotrophic nanoflagellates: Analysis of food vacuole contents. Limnol. Oceanogr., 44, 1565-1570.

Fahnenstiel G.L. \& Carrick H.J. 1991. - Physiological characteristics and food-web dynamics of Synechococcus in Lakes Huron and Michigan. Limnol. Oceanogr., 36, 219-234.

Fahnenstiel G.L., Redalje D.G. \& Lohrenz S.E. 1994. - Has the importance of photoautotrophic picoplankton been overstimated? Limnol. Oceanogr., 39, 432-438.

Gaedke U. \& Weisse T. 1998. - Seasonal and interannual variability of picocyanobacteria in Lake Constance (1987-1997). Arch. Hydrobiol. Spec. Issues Advanc. Limnol., 53, 143-158.

Happey-Wood Ch.M. 1994. - Diurnal variation in the contribution of autotrophic picoalgae and heterotrophic bacteria to planktonic production in an upland lake. J. Plankton Res., 16, 433-455.

Happerle D. \& Krienitz L. 2001. - Systematics and ecology of chlorophyte picoplankton in German inland waters along a nurtient gradient. Internat. Rev. Hydrobiol., 86, 269-284.

Jacquet S., Lennon J-F., Marie D., Vaulot D. 1998. - Picoplankton population dynamics in coastal waters of the northwestern Mediterranean Sea. Limnol Oceanogr., 43, 1916-1931.

Jasser I. 1993. - The abundance and biovolume of picoplankton in two lakes with different trophy. Pages 199-202 in Limnological bases of lake management Salanki J \& Biró P. (eds). Tihany, Hungary.

Komarek J. \& Anagnostidis K. 1999. - Cyanoprokaryota 1. In Teil: Chroococcales. Susswasserflora von Mitteleuropa 19/1. Ettl H., Gärtner G. \& Heynig H. (eds). Gustav Fischer Verlag Jena, 548 p.

Komárková J. 2002. - Do cyanobacterial pikoplankton exist in eutrophic reservoirs? Verh. int. Ver. Limnol., 28, 497-500.

MacIsaac E.A. \& Stockner J.G. 1993. - Enumeration of phototrophic picoplankton by autofluorescence microscopy. Pages 187-197 in The handbook of methods in aquatic microbial ecology. Kemp P.F, Sherr B.F., Sherr E.B \& Cole J.J. (eds). CRC Press, Boca Raton, FL.
Malinsky-Rushansky N., Berman T. \& Dubinsky Z. 1995. - Seasona dynamics of picophytoplankton in Lake Kinneret, Israel. Freshwat. Biol., 34, 241-254.

Padisák J. \& Dokulil M. 1994. - Meroplankton dynamics in saline, turbulent, turbid shallow lake (Neusiedlersee, Austria and Hungary). Hydrobiologia, 289, 23-42.

Padisak J., Krienitz L, Koschel R. \& Nedoma J. 1997. - Deep-layer autotrophic pikoplankton maximum in the oligotrophic Lake Stechlin, Germany: origin, activity, development and erosin. Eur. J. Phycol., 32, 403-416.

Passoni S. \& Callieri C. 2000. - Picocyanobacteria single forms, aggregates and microcolonies: survival strategy or species succession? Verh. int. Ver. Limnol., 27, 1879-1883.

Pick F.R. \& Agbeti M. 1991. - The seasonal dynamics and composition of photosynthetic picoplankton communities in temperate lakes in Ontario, Canada. Int. Rev. ges. Hydrobiol., 76, 565-580.

Porter K.G. \& Feig Y.S. 1980. - The use of DAPI for identifying and counting aquatic microflora. Limnol. Oceanogr., 25, 943-948.

Schallenberg M. \& Burns C.W. 2001. - Tests of autotrophic picoplankton as early indicators of nutrient enrichment in an ultraoligotrophic lake. Freshwat. Biol., 46, 27-37.

Simek K., Macek M., Pernthaler J., Straškrabová V. \& Psenner J. 1996. - Can freshwater planktonic ciliates survive on a diet of picoplankton? J. Plankt. Res., 18, 597-613.

Sime-Ngando T. 1995. - Population dynamics of autotrophic picoplankton in relation to environmental factors in a productive lake. Aquat. Sci., 57, 91-105.

Sommaruga R. \& Robarts R.D. 1997. - The significance of autotrophic ahd heterotrophic picoplankton in hypertrophic ecosystems. FEMS Microbiology Ecology, 24, 187-200.

Sondergaard M. 1991. - Phototrophic picoplankton in temperate lakes: seasonal abundance and importance along a trophic gradient. Int. Rev. ges. Hydrobiol., 76, 505-522.

Stockner J.G. 1988. - Phototrophic picoplankton: an overview from marine and freshwater ecosystems. Limnol. Oceanogr., 33, 765775 .

Stockner J.G. 1991. - Autotrophic picoplankton in freshwater ecosystems: the view from the summit. Int. Rev. ges. Hydrobiol., 76, 483-492.

Stockner J.G. \& Antia N.J. 1986. - Algal picoplankton from marine and freshwater ecosystems: a multidisciplinary perspective. Can J. Fish. Aquat. Sci., 43, 2472-2503.

Stockner J.G., Callieri C. \& Cronberg G. 2000. - Picoplankton and other non-bloom-forming cyanobacteria in lakes. Pages 195-231 in The Ecology of Cyanobacteria. Whittion B.A. \& Potts M. (eds). Kluwer Academic Publishers, Netherlands.

Stockner J.G. \& Shortreed K.S. 1991. - Autotrophic picoplankton: community composition, abundance and distribution across a gradient of oligotrophic British Columbia and Yukon territory lakes. Int. Rev. ges. Hydrobiol., 76, 581-601.

Stockner J.G. \& Shortreed K.S. 1994. - Autotrophic picoplankton community dynamics in a pre-alpine lake in British Columbia, Canada. Hydrobiologia, 274, 133-142.

Szelag-Wasielewska E. 1999a. - Fluktuacje sezonowe fitoplanktonu jako wyraz zmian zachodzacych w pelagialu jezior. Pages 245 254 in Naturalne i antropogeniczne przemiany jezior. Choinski A. \& Jańczak J. (eds). IMiGW, Warszawa.

Szelag-Wasielewska E. 1999b. - Autotrophic picoplankton dynamics in a small shallow lake. Hydrobiologia, 408/409, 301-306.

Szelag-Wasielewska E. 2002. - Autotrophic picoplankton during summer phytoplankton development: diel abundance and productivity. Verh. int. Ver. Limnol., 28, 1640-1643. 
Weisse T. 1993. - Dynamics of autotrophic picoplankton in marine and freshwater ecosystems. Pages 327-370 in Advances in Microbial Ecology. Jones J.G (ed.), Vol. 13:. Plenum Press, New York. Weisse T. \& Kenter U. 1991. - Ecological characteristics of autotrophic picoplankton in a prealpine lake. Int. Rev. ges. Hydrobiol., 76, 493-504.
Vörös L., Gulyás P. \& Németh J. - 1991. Occurrence, dynamics and production of picoplankton in Hungarian shallow lakes. Int. Rev. ges. Hydrobiol., 76, 617-629. 